E-ISSN: 2502-3101 P-ISSN: 2302-528x

http://ojs.unud.ac.id/index.php/jmhu

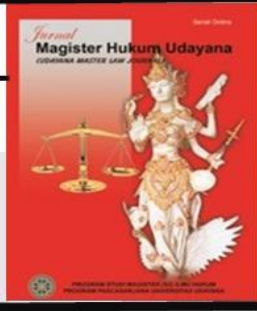

\title{
Pertanggungjawaban Pidana Bagi Pelaku Tindak Pidana Jual Beli Organ Tubuh Manusia
}

\author{
Adhyaksa Mahasena ${ }^{1}$ \\ ${ }^{1}$ Program Studi Magister Ilmu Hukum, Fakultas Hukum, Universitas Udayana \\ E-mail: dhyka.lawliet@gmail.com
}

\begin{tabular}{l}
\hline Info Artikel \\
\hline Masuk: 5 Maret 2018 \\
Diterima : 18 April 2018 \\
Terbit : 28 Mei 2018 \\
Keywords : \\
Criminal Liability, Trafficking, \\
Human Organs \\
\\
Kata kunci: \\
Pertanggungjawaban Pidana, \\
Jual Beli, Organ Tubuh \\
Manusia \\
Corresponding Author: \\
Adhyaksa Mahasena, E-mail: \\
dhyka.lawliet@gmail.com \\
DOI : \\
10.24843/JMHU.2018.v07.io1. \\
p07
\end{tabular}

\begin{abstract}
The unlimited economic necessaries but not accompanied by adequate income, encourage people to commercialize without thinking of any consequences. One such activity is by human organs trafficking. Any negative consequences arising from such activities should be criminally justified on the basis of applicable rules. The legal issues in this writing are how criminal liability for the perpetrator of human organs trafficking in Indonesian criminal law and how criminal liability for the perpetrator of human organs trafficking in the renewal of Indonesian criminal law. The type of research is normative legal research. The conclusion of this research is according to the Indonesian criminal laws and the draft of national criminal laws, individuals and corporation can be charged with criminal responsibility if it's proven to committing the criminal act of human organs trafficking.
\end{abstract}

\begin{tabular}{l}
\hline Abstrak \\
\hline Kebutuhan ekonomi yang kian hari makin tidak terbatas \\
namun tidak sejalan pula dengan finansial yang didapat, \\
mengakibatkan adanya dorongan untuk melakukan \\
kegiatan komersial tanpa memikirkan segala resiko yang \\
ditimbulkan. Salah satunya adalah dengan melakukan jual \\
beli organ tubuh manusia. Berbagai akibat negatif yang \\
timbul dari kegiatan tersebut, seharusnya dapat \\
dipertanggungjawabkan secara pidana berdasarkan aturan \\
yang berlaku. Rumusan masalah dalam penulisan ini \\
adalah bagaimana pertanggungjawaban pidana bagi \\
pelaku tindak pidana jual beli organ tubuh manusia dalam \\
hukum positif di Indonesia dan bagaimana \\
pertanggungjawaban pidana bagi pelaku tindak pidana \\
jual beli organ tubuh manusia dalam pembaharuan hukum \\
pidana Indonesia. Jenis penelitian yang digunakan adalah \\
jenis penelitian hukum normatif. Kesimpulan dari hasil \\
penelitian ini adalah menurut hukum positif dan RUU- \\
KUHP Nasional, orang perseorangan maupun korporasi \\
dapat dibebani pertanggungjawaban secara pidana jika \\
terbukti melakukan tindak pidana jual beli organ tubuh \\
manusia.
\end{tabular}




\section{Pendahuluan}

Laju perkembangan ilmu pengetahuan dan teknologi merupakan salah satu indikator penentu kemajuan suatu negara. Kondisi yang demikian dapat dimanfaatkan sebagai pemenuhan kebutuhan masyarakat yang majemuk dan borderless, termasuk di bidang kesehatan. Hal ini tampak dari pemanfaatan perkembangan ilmu pengetahuan dan teknologi sebagai solusi dalam penyelesaian masalah-masalah kesehatan yang meliputi pengobatan atau penyembuhan penyakit, pemulihan, perawatan dan pelayanan kesehatan. Tindakan-tindakan yang berkaitan dengan dunia kesehatan disebut tindakan medis. Salah satu tindakan medis yang dapat ditempuh dalam rangka usaha penyembuhan penyakit adalah melalui tindakan transplantasi organ tubuh. Perkembangan transplantasi organ tubuh manusia semakin berkembang, tidak hanya organ jantung manusia, namun berkembang ke cangkok ginjal, hati, dan beberapa organ lain termasuk jaringan tubuh manusia seperti jaringan otot maupun syaraf. ${ }^{1}$

Mengenai transplantasi organ tubuh manusia, tindakan ini sudah menjadi salah satu hal yang mengundang polemik dalam dunia medis. Pengertian transplantasi secara yuridis adalah rangkaian tindakan kedokteran untuk pemindahan alat dan atau jaringan tubuh manusia yang berasal dari tubuh sendiri atau tubuh orang lain dalam rangka pengobatan untuk menggantikan alat dan atau jaringan tubuh yang tidak berfungsi dengan baik. ${ }^{2}$ Transplantasi organ dan atau jaringan tubuh manusia merupakan tindakan medik yang sangat bermanfaat bagi pasien dengan gangguan fungsi organ tubuh yang berat. Tindakan transplantasi tampaknya bukan menjadi hal yang baru dalam pemanfaatan kemajuan ilmu pengetahuan dan teknologi di dunia medis, namun tentu saja tindakan ini tidak dapat dilakukan secara sembarangan. Penyembuhan penyakit melalui transplantasi sangat berkembang dan sangat diminati masyarakat karena memiliki tingkat keberhasilan yang sangat besar. ${ }^{3}$ Transplantasi organ tubuh dapat dilakukan dengan didasari pertimbangan dari sudut pandang agama, budaya, hukum, etika, moral, sosial dan ekonomi dalam kehidupan masyarakat.

Permasalahan muncul ketika pendonor organ tubuh manusia merupakan orang yang masih hidup. Pasien pengidap penyakit tertentu mengalami permasalahan yang besar tidak hanya dalam hal keuangan tapi juga mengalami hambatan dalam hal mencari

\footnotetext{
${ }^{1}$ Putra, F. A. (2013). Analisis Yuridis Perundang-undangan Terkait Tindak Pidana Jual Beli Organ Tubuh untuk Kepentingan Transplantasi Organ Ginjal (Studi Perbandingan antara Indonesia dengan Philipina). Kumpulan Jurnal Mahasiswa Fakultas Hukum, 1(2).

2 Pengertian mengenai transplantasi ini termaktub jelas dalam Pasal 1 huruf e Peraturan Pemerintah Republik Indonesia Nomor 18 Tahun 1981 tentang Bedah Mayat Klinis dan Bedah Mayat Anatomis serta Transplantasi Alat atau Jaringan Tubuh Manusia. Perlu diketahui bahwa Peraturan Pemerintah (PP) ini merupakan peraturan pelaksana dari Undang-Undang Nomor 9 Tahun 1960 tentang Pokok-Pokok Kesehatan dan hingga sekarang PP ini belum dicabut meskipun undang-undang terkait kesehatan sudah beberapa kali mengalami perubahan (pembaharuan).

3 Simanjuntak, N. A. L. (2017). Kajian Yuridis Ketentuan Pidana Dalam Pasal 192 UndangUndang Nomor 36 Tahun 2009 Tentang Kesehatan Terkait Dengan Jual Beli Organ Tubuh Manusia Untuk Tindakan Transplantasi. Kumpulan Jurnal Mahasiswa Fakultas Hukum.
} 
organ tubuh. ${ }^{4}$ Pada awalnya, tindakan transplantasi dilakukan atas donor dari pihak keluarga dengan alasan kemanusiaan. Namun seiring berjalannya waktu, kebutuhan dan permintaan akan donor organ tubuh oleh pasien yang mengidap penyakit tertentu semakin meningkat. Hal ini mengakibatkan dimungkinkannya pendonor organ tubuh berasal dari luar pihak keluarga. Timpangnya jumlah permintaan organ tubuh dibandingkan dengan jumlah pasien inilah yang kemudian menyuburkan praktek ilegal jual beli organ tubuh. ${ }^{5}$ Kondisi yang demikian sudah tentu mengundang pergeseran nilai kemanusiaan ke arah komersial (mencari keuntungan) dalam tindakan transplantasi, yaitu salah satunya melalui transaksi jual beli organ tubuh. Mahalnya biaya untuk melakukan transplantasi organ tubuh memicu terjadinya perbuatan-perbuatan yang tidak baik oleh oknum-oknum yang tidak bertanggung jawab untuk memenuhi permintaan, sehingga tidak dapat dihindarkan untuk terjadinya tindak pidana jual beli organ tubuh manusia. ${ }^{6}$ Komersial dalam kegiatan transplantasi organ tubuh tentunya sangat bertentangan dengan nilai kemanusiaan yang menjadi fokus tujuan utama dalam melakukan tindakan transplantasi organ tubuh terutama bagi donor hidup. ${ }^{7}$

Salah satu transplantasi organ tubuh yang sering terjadi adalah transplantasi ginjal. ${ }^{8}$ Media online banyak memuat berita mengenai jual beli organ tubuh, akan tetapi hal ini sudah menjadi pemandangan yang biasa. Parahnya lagi tidak ada satu kasus pun mengenai jual beli organ tubuh yang sampai pada pengadilan padahal kegiatan ini telah dilakukan dengan terang-terangan (terbuka). ${ }^{9}$ Motif para penjual organ tubuh manusia sangat beragam, namun mayoritas menggunakan dalih pemenuhan tuntutan ekonomi yang makin lama makin meningkat. Kebutuhan ekonomi yang kian hari makin membengkak, tidak sejalan dengan input finansial yang didapat. Walaupun sudah bekerja keras demi mendapatkan upah yang layak, namun tetap saja ada kebutuhan para penjual organ tubuh manusia yang tidak terpenuhi. Seperti halnya berita yang ditayangkan oleh salah satu stasiun televisi Indonesia, Estriati warga Desa Pepedan, Kabupaten Tegal, Jawa Tengah berniat menjual salah satu ginjalnya seharga Rp 200.000.000,- (dua ratus juta rupiah) kepada siapa saja yang berminat. Himpitan ekonomi membuatnya berbuat nekat, karena sejak 3 bulan lalu sang suami tak pernah pulang dan tidak mengirimkan uang untuk keluarga. ${ }^{10}$ Niat pendonoran ini jelas-jelas

4 Herani, I. (2017). Organ Donation? Why Not..: Keputusan Untuk Mendonorkan Organ Tubuh (studi pada living donor). PSIKOVIDYA, 21(2).

${ }^{5}$ Woriassy, E. Y. (2012). Efektifitas Ketentuan Hukum Tentang Tindak Pidana Jual Beli Organ Dan Atau Jaringan Tubuh (Doctoral dissertation, UAJY

${ }^{6}$ Laki, Y. A. (2015). Tindak Pidana Perdagangan Organ Tubuh Manusia Menurut Ketentuan Hukum Positif Indonesia. Lex et Societatis, 3(9).

7 Aristantie, D. W. (2014). Perjanjian Antara Pendonor Dan Pasien Yang Membutuhkan "Ginjal" Untuk Transplantasi (Analisis Pasal 64 Undang-Undang Republik Indonesia No 36 Tahun 2009 Tentang Kesehatan). Kumpulan Jurnal Mahasiswa Fakultas Hukum, 1(1).

8 KHALIFAH, H., \& Innaka, R. A. (2016). Tinjauan Yuridis Terhadap Praktik Jual-Beli Ginjal Berdasarkan Peraturan Perundang-Undangan di Indonesia (Doctoral dissertation, Universitas Gadjah Mada).

9 Pasaribu, M., Hamdan, M., \& Lubis, R. (2014). Perdagangan Organ Tubuh Manusia Untuk Tujuan Transplantasi Dari Perspektif Kebijakan Hukum Pidana Di Indonesia. Jurnal Mahupiki, 2(1).

10 Video: Terdesak Himpitan Ekonomi, Ibu Ini Berniat Jual Ginjal, tersedia pada url: m.liputan6.com/tv/read/2621557/video-terdesak-himpitan-ekonomi-ibu-ini-berniat-jual-ginjal, diakses pada tanggal 10 Oktober 2016 pukul 22.38 WITA. 
ditulis menjadi pemberitaan utama oleh berbagai media masa, yang kemudian diketahui oleh banyak orang, bukan pemberitaan yang sembunyi-sembunyi. ${ }^{11}$

Ketika komersialisasi terhadap organ tubuh manusia mulai merebak dan menjamur di masyarakat melalui transaksi jual beli, maka dari perspektif hukum pidana seharusnya tindakan tersebut diatur di dalam peraturan perundang-undangan sebagai langkah penjaminan terhadap kepastian hukum. Sebagai bentuk kodifikasi hukum pidana materiil di Indonesia, Kitab Undang-Undang Hukum Pidana (selanjutnya disebut dengan KUHP) tidak mengatur jual beli organ tubuh manusia, melainkan diatur secara khusus melalui peraturan perundang-undangan di luar KUHP yakni melalui UndangUndang RI Nomor 36 Tahun 2009 tentang Kesehatan (selanjutnya disebut dengan UU Kesehatan) dan Undang-Undang RI Nomor 23 Tahun 2002 tentang Perlindungan Anak (selanjutnya disebut dengan UU Perlindungan Anak). Ketentuan pidana tersebut merupakan terobosan baru dalam upaya memberantas mafia perdagangan organ tubuh manusia. ${ }^{12}$

Maraknya praktek jual beli organ tubuh manusia yang dilakukan secara terselubung dikarenakan pemerintah saat ini belum menggalakkan secara maksimal aturan pidana materiil yang ada terkait hal tersebut. Kebutuhan akan organ yang sangat tinggi berdampak pada semakin banyaknya jual-beli organ tubuh manusia di pasar gelap. ${ }^{13}$ Hal tersebut menggambarkan bahwa masih banyaknya praktek jual beli organ tubuh manusia dilakukan secara terselubung, bahkan tidak bisa dipungkiri adanya keterlibatan tenaga kesehatan dan rumah sakit dalam proses jual beli tersebut berlangsung. Kembali, dalih kemanusiaan akan menyamarkan keterlibatan pihakpihak yang terkait. Peran dan tugas yang dilakoni masing-masing subjek hukum yang terlibat dalam rangkaian jual beli organ tubuh manusia tidak mudah untuk dilacak, sehingga menyulitkan aparat untuk menentukan pertanggungjawaban pidana terhadap para pelakunya. Untuk itu, penulis ingin mengkaji lebih lanjut mengenai pertanggungjawaban pidana bagi pelaku tindak pidana jual beli organ tubuh manusia.

Berdasarkan latar belakang di atas, maka dapat dirumuskan ke dalam beberapa rumusan masalah sebagai berikut, pertama Bagaimana pertanggungjawaban pidana bagi pelaku tindak pidana jual beli organ tubuh manusia menurut hukum positif di Indonesia? Dan kedua Bagaimana pertanggungjawaban pidana bagi pelaku tindak pidana jual beli organ tubuh manusia dalam pembaharuan hukum pidana di Indonesia?

Penelitian ini merupakan karya ilmiah asli yang memiliki kontribusi baru dan penting dalam pengembangan ilmu pengetahuan. Adapun karya ilmiah yang terkait dengan karya ilmiah yang Penulis tulis yaitu: Pertama, oleh Maslihati Nur Hidayati tahun 2012 yang berjudul Upaya Pemberantasan dan Pencegahan Perdagangan Orang Melalui Hukum Internasional dan Hukum Positif Indonesia yang mendeskripsikan tentang bagaimana upaya-upaya hukum yang dilakukan untuk memberantas dan mencegah perdagangan orang yang melingkupi pula jual beli organ tubuh manusia, melalui

${ }^{11}$ Bintoro, A. (2018). Memahami Nilai Etika Dan Moral Donasi Organ. Jurnal Orientasi Baru, 25(1).

${ }^{12}$ Iqbal, M. (2017). Perkembangan Kejahatan Dalam Upaya Penegakan Hukum Pidana: Penanggulangan Kejahatan Profesional Perdagangan Organ Tubuh Manusia. Jurnal Universitas Pamulang, 2(1).

${ }^{13}$ Suminar, S. R. (2017). Aspek Hukum dan Fiqih Tentang Transaksi Organ Tubuh untuk Transplantasi Organ Tubuh Manusia. Syiar Hukum, 12(1), 33-48. 
instrumen hukum internasional dan nasional. ${ }^{14}$ Kedua, oleh Saptaning Ruju Paminto tahun 2017 dengan judul Dehumanisasi Penjualan Organ Tubuh Manusia Berdasarkan Hukum Positif yang mendeskripsikan mengenai kebijakan formulasi terhadap tindak pidana teknologi informasi penjualan online organ tubuh manusia saat ini. ${ }^{15}$ Selanjutnya ketiga, karya ilmiah yang ditulis oleh Reggy Lintang Tahun 2013 yang berjudul Aspek Hukum Terhadap Pemanfaatan Organ Tubuh Manusia Untuk Kelangsungan Hidup mendeskripsikan mengenai modus operandi dan pengaturan terkait pemanfaatan organ tubuh manusia untuk kelangsungan hidup. ${ }^{16}$ Jelas nampak perbedaan dari karya ilmiah tersebut dengan karya ilmiah yang dibuat oleh Penulis. Dari ketiga karya ilmiah terdahulu diatas belum satupun yang mengkaji dan menganalisis terkait pertanggungjawaban pidana bagi pelaku tindak pidana jual beli organ tubuh manusia.

Tujuan dari penelitian ini adalah untuk menganalisis dan mendeskripsikan mengenai pertanggungjawaban pidana bagi pelaku tindak pidana jual beli organ tubuh manusia, baik dari perspektif hukum positif maupun dalam pembaharuan hukum pidana di Indonesia.

\section{Metode Penelitian}

Penelitian ilmiah dipandang sebagai cara kerja keilmuan yang salah satunya ditandai dengan menggunakan metode (dalam bahasa Yunani disebut Methodos, Meta berarti di atas, sedangkan thodos berarti suatu jalan, suatu cara). ${ }^{17}$ Jika dilihat dari segi jenisnya, maka penelitian hukum dapat dibedakan menjadi tiga jenis yaitu: penelitian hukum normatif, penelitian hukum empiris, atau gabungan keduanya. ${ }^{18}$ Penulisan karya ilmiah ini menggunakan jenis penelitian hukum normatif. Penelitian hukum normatif berarti penelitian yang bertitik berat terhadap bahan hukum berupa aturan atau norma hukum positif dan menjadi bahan acuan utama dalam penelitian. ${ }^{19}$ Sedangkan pendekatan yang digunakan dalam penelitian ini adalah pendekatan perundangundangan (the statute approach) yaitu mengkaji serta menganalisis peraturan perundang-undangan yang berkaitan dengan isu hukum yang sedang diteliti. Sumber bahan hukum yang digunakan dalam penelitian ini terdiri atas bahan hukum primer, bahan hukum sekunder, dan bahan hukum tersier.

\section{Hasil dan Pembahasan}

\subsection{Pertanggungjawaban Pidana Bagi Pelaku Tindak Pidana Jual Beli Organ Tubuh} Manusia Dalam Hukum Positif di Indonesia

Tindak pidana jual beli organ tubuh manusia telah diakomodir di Indonesia melalui beberapa peraturan perundang-undangan yakni Undang-Undang RI Nomor 36 Tahun 2009 tentang Kesehatan dan Undang-Undang RI Nomor 23 Tahun 2002 tentang

${ }^{14}$ Hidayati, M. N. (2012). Upaya Pemberantasan dan Pencegahan Perdagangan Orang Melalui Hukum Internasional dan Hukum Positif Indonesia. Jurnal Al-Azhar Indonesia Seri Pranata Sosial, 1(3), 163-175.

${ }^{15}$ Paminto, S. R. (2017). Dehumanisasi Penjualan Organ Tubuh Manusia Berdasarkan Hukum Positif. Jurnal Wawasan Yuridika, 1(2), 174-190.

${ }^{16}$ Lintang, R. (2013). Aspek Hukum Terhadap Pemanfaatan Organ Tubuh Manusia Untuk Kelangsungan Hidup. LEX ET SOCIETATIS, 1(5). 132-143.

${ }^{17}$ Ibrahim, J. (2006). Teori dan Metodeologi Penelitian Hukum Normatif. Malang. Bayu Publishing. h. 26.

${ }^{18}$ Soekanto, S. (2010). Pengantar Penelitian Hukum,Jakarta. UII Press. h. 201.

${ }^{19}$ Ibid. 
Perlindungan Anak. Kedua undang-undang ini sejalan mengatur secara tegas bahwa tindakan komersialisasi organ tubuh manusia dengan cara jual beli dilarang, sehingga bagi subjek hukum yang melakukan hal tersebut diancam dengan sanksi pidana sesuai dengan aturan yang berlaku.

Rumusan tindak pidana jual beli organ tubuh manusia dalam UU Kesehatan terdapat pada Bab XX tentang Ketentuan Pidana, pada Pasal 192 yang mengatur, "Setiap orang yang dengan sengaja memperjualbelikan organ atau jaringan tubuh dengan dalih apa pun sebagaimana dimaksud dalam Pasal 64 ayat (3) dipidana dengan pidana penjara paling lama 10 (sepuluh) tahun dan denda paling banyak Rp 1.000.000.000,00 (satu miliar rupiah)." Dalam pasal a quo, subjek tindak pidana jual beli organ tubuh manusia yang dapat dipertanggungjawabkan pidana disebut dengan "setiap orang". Akan tetapi tidak ada ketentuan pasal yang menyebutkan tentang apa yang dimaksud dengan setiap orang. Sehingga secara umum, subjek "setiap orang" ini ditujukan pada "orang perseorangan". Namun, berdasarkan Pasal 201 UU Kesehatan, korporasi diakui sebagai subjek tindak pidana jual beli organ tubuh manusia beserta ancaman pidananya diatur tersendiri.

Rumusan tindak pidana jual beli organ tubuh anak dalam UU Perlindungan Anak terdapat pada Bab XII tentang Ketentuan Pidana, pada Pasal 85 ayat (1) yang mengatur, "Setiap orang yang melakukan jual beli organ tubuh dan/atau jaringan tubuh anak dipidana dengan pidana penjara paling lama 15 (lima belas) tahun dan/atau denda paling banyak Rp 300.000.000,00 (tiga ratus juta rupiah)." Dalam pasal a quo, subjek tindak pidana jual beli organ tubuh manusia yang dapat dipertanggungjawabkan pidana juga disebut dengan "setiap orang". Berbeda dengan ketentuan UU Kesehatan di atas, Pasal 1 angka 16 UU Perlindungan Anak dengan tegas menyebutkan bahwa yang dimaksud dengan "setiap orang adalah orang perseorangan atau korporasi". Hanya saja ancaman pidana bagi korporasi diatur tersendiri dalam Pasal 90 UU Perlindungan Anak.

Berbicara mengenai pertanggungjawaban pidana bagi pelaku tindak pidana jual beli organ tubuh manusia, tentunya terdapat perbedaan antara konsep pertanggungjawaban pidana bagi orang perseorangan dengan korporasi, yakni sebagai berikut:

1) Pertanggungjawaban pidana bagi orang perseorangan sebagai pelaku tindak pidana jual beli organ tubuh manusia

Suatu syarat yang diperlukan untuk adanya pertanggungjawaban pidana adalah si pembuat harus mampu bertanggung jawab, dengan lain perkataan harus ada kemampuan bertanggung jawab dari si pembuat. Mengenai apa yang dimaksud dengan kemampuan bertanggung jawab (toerekeningsvatbaarheid) ini harus dicari dalam doktrin atau Memorie van Toelichting $(M v T),{ }^{20}$ karena undang-undang tidak menyebutkan mengenai hal ini.

Menurut Sudarto, pengertian pertanggungjawaban dalam hukum pidana dapat disamakan dengan pengertian kesalahan dalam arti yang seluas-luasnya. Sudarto mengemukakan bahwa pertanggungjawaban pidana (kesalahan dalam arti yang seluas-luasnya) terdiri atas beberapa unsur, yaitu:

20 Widnyana, I. M. (2010) Asas-asas Hukum Pidana. Jakarta. Fikahati Aneska. h. 58. 
a. Adanya kemampuan bertanggung jawab pada si pembuat, artinya keadaan jiwa si pembuat harus normal.

b. Hubungan batin antara si pembuat dengan perbuatannya, yang berupa kesengajaan (dolus) atau kealpaan (culpa).

c. Tidak adanya alasan yang menghapus kesalahan atau tidak adanya alasan pemaaf. ${ }^{21}$

Menurut Memorie van Toelichting (MvT), tidak ada kemampuan bertanggung jawab pada si pembuat, apabila:

a. Si pembuat tidak ada kebebasan untuk memilih antara berbuat dan tidak berbuat mengenai apa yang dilarang atau diperintahkan oleh undangundang.

b. Si pembuat ada dalam suatu keadaan yang sedemikian rupa, sehingga tidak dapat menginsyafi bahwa perbuatannya itu bertentangan dengan hukum dan tidak dapat menentukan akibat perbuatannya.

Hal yang menjadi persoalan dalam kemampuan bertanggung jawab adalah apakah seseorang itu merupakan norm addressat (sasaran norma) yang mampu. Seorang terdakwa pada dasarnya dianggap bertanggung jawab, kecuali dinyatakan sebaliknya. KUHP tidak memuat perumusan mengenai kapan seseorang mampu bertanggung jawab, tetapi hanya memuat ketentuan yang menunjuk ke arah itu, seperti ditentukan dalam Buku I, Bab III, Pasal 44 KUHP, yang berbunyi "Barang siapa melakukan perbuatan yang tidak dapat dipertanggungjawabkan kepadanya, karena jiwanya cacat dalam tumbuhnya atau terganggu jiwanya karena penyakit, tidak dipidana" ${ }^{22}$

Ketentuan ini sebenarnya tidak memuat apa yang dimaksud dengan "tidak mampu bertanggung jawab", tetapi hanya memuat suatu alasan yang terdapat pada diri si pembuat, sehingga perbuatan yang dilakukannya itu tidak dapat dipertanggungjawabkan kepadanya. Dalam keadaan yang demikian, si pembuat tidak punya kebebasan kehendak dan tidak dapat menentukan kehendaknya terhadap perbuatannya. Apabila Pasal 44 KUHP itu ditelaah, maka akan terlihat 2 (dua) hal, yaitu: (a) Penentuan bagaimana keadaan jiwa si pembuat. Yang bisa dan berwenang menentukan keadaan jiwa si pembuat pada saat ia melakukan perbuatan adalah dokter penyakit jiwa (psikiater); (b) Menentukan hubungan kausal antara keadaan jiwa yang demikian itu dengan perbuatannya. Yang berwenang menentukan hal ini adalah hakim yang memeriksa perkara tersebut. ${ }^{23}$

Tidak dapat dipisahkan antara kesalahan dan pertanggungjawaban atas perbuatan. Orang yang melakukan dengan kesalahan saja yang dibebani tanggung jawab atas tindak pidana yang dilakukannya. ${ }^{24}$ Menurut Moeljatno, kesalahan adalah adanya keadaan psikis yang tertentu pada orang yang melakukan perbuatan pidana dan adanya hubungan antara keadaan tersebut dengan perbuatan yang dilakukan yang sedemikian rupa, hingga orang itu dapat dicela karena melakukan perbuatan tadi. ${ }^{25}$

${ }^{21}$ Ibid., h. 68.

22 Ibid., h. 58-59.

${ }^{23}$ Ibid., h. 59-60.

${ }^{24}$ Chazawi, A. (2007). Malpraktik Kedokteran (Tinjauan Norma dan Doktrin Hukum). Malang. Bayumedia Publishing. h. 151.

${ }^{25}$ Widnyana, I. M. Op.cit., h. 65. 
Hal ini berhubungan dengan kesengajaan ataupun kealpaan sebagai bentuk-bentuk dari kesalahan.

Syarat lain untuk adanya pertanggungjawaban pidana harus memenuhi tidak adanya alasan penghapus kesalahan atau alasan pemaaf. Alasan pemaaf menyangkut pribadi si pembuat, dalam arti bahwa orang ini tidak dapat dicela (menurut hukum) dengan perkataan lain ia tidak bersalah atau tidak dapat dipertanggungjawabkan, meskipun perbuatannya bersifat melawan hukum. Jadi disini ada alasan yang menghapuskan kesalahan si pembuat sehingga tidak mungkin mendapat pemidanaan. Alasan pemaaf terdapat dalam Pasal 44 KUHP (tidak mampu bertanggungjawab), Pasal 49 ayat (2) KUHP (noodweer exces), Pasal 51 ayat (2) KUHP (dengan itikad baik melaksanakan perintah jabatan yang tidak sah), adapun mengenai Pasal 48 KUHP (daya paksa) dapat merupakan alasan pemaaf atau alasan pembenar. ${ }^{26}$

Konsep pertanggungjawaban pidana yang diuraikan di atas pada dasarnya berlaku terhadap subjek tindak pidana "orang perseorangan" sebagaimana dimaksud dalam Pasal 192 UU Kesehatan dan Pasal 85 ayat (1) UU Perlindungan Anak. Jadi dalam hal jual beli organ tubuh manusia dilakukan oleh orang perseorangan, maka ia dapat dipertanggungjawabkan pidana apabila ia memiliki kemampuan bertanggungjawab, adanya kesalahan, dan tidak adanya alasan penghapus kesalahan atau alasan pemaaf.

Orang perseorangan yang dapat dipertanggungjawabkan pidana melakukan tindak pidana jual beli organ tubuh manusia berdasarkan Pasal 192 UU Kesehatan, dapat dipidana dengan pidana penjara paling lama 10 (sepuluh) tahun dan denda paling banyak Rp 1.000.000.000,00 (satu miliar rupiah). Sedangkan khusus bagi orang perseorangan yang dapat dipertanggungjawabkan pidana melakukan tindak pidana jual beli organ tubuh anak berdasarkan Pasal 85 ayat (1) UU Perlindungan Anak, dapat dipidana dengan pidana penjara paling lama 15 (lima belas) tahun dan/atau denda paling banyak Rp 300.000.000, 00 (tiga ratus juta rupiah).

2) Pertanggungjawaban pidana bagi korporasi sebagai pelaku tindak pidana jual beli organ tubuh manusia

Dapat diidentifikasi bahwa korporasi dapat dipertanggungjawabkan pidana sebagai pelaku tindak pidana jual beli organ tubuh manusia sebagaimana diatur dalam Pasal 201 UU Kesehatan dan Pasal 90 UU Perlindungan Anak. Namun, UU Kesehatan dan UU Perlindungan Anak tidak menyebutkan mengenai pengertian korporasi, sehingga dapat dicari dalam undang-undang lain yang terkait (misalnya UU PTPPO), bahwa korporasi adalah kumpulan orang dan/atau kekayaan yang terorganisasi baik merupakan badan hukum maupun bukan badan hukum. Selain itu, tidak disebutkan mengenai konsep/model yang digunakan dalam menentukan pertanggungjawaban pidana korporasi, sehingga dapat dicari dalam doktrin.

Mengenai kedudukan sebagai pembuat dan sifat pertanggungjawaban pidana korporasi, terdapat model pertanggungjawaban korporasi, yakni:

a. Pengurus korporasi sebagai pembuat dan penguruslah yang bertanggungjawab.

b. Korporasi sebagai pembuat dan pengurus bertanggungjawab.

${ }^{26}$ Gunadi, I. \& Efendi, J. (2011).Cepat dan Mudah Memahami Hukum Pidana. Jakarta.Prestasi Pustaka Publisher. h. 100. 
c. Korporasi sebagai pembuat dan juga sebagai yang bertanggungjawab. ${ }^{27}$

Adapun teori-teori pertanggungjawaban pidana korporasi antara lain:

1. Doktrin pertanggungjawaban pidana langsung (direct liability doctrine) atau teori identifikasi (identification theory)

Menurut teori ini, perbuatan/kesalahan pejabat senior (senior officer) diidentifikasi sebagai perbuatan/kesalahan korporasi. Disebut juga teori/doktrin "alter ego" atau "teori organ":

a) Arti sempit (Inggris): hanya perbuatan pejabat senior (otak korporasi) yang dapat dipertanggungjawabkan kepada korporasi.

b) Arti luas (Amerika Serikat): tidak hanya pejabat senior/direktur, tetapi juga agen di bawahnya. ${ }^{28}$

Teori ini mendasarkan pada pandangan bahwa tindakan orang-orang tertentu adalah benar-benar menggambarkan tindakan korporasi. Atau dengan kata lain korporasi bisa melakukan delik secara langsung melalui orang-orang yang sangat berhubungan erat dengan korporasi dan dipandang sebagai perusahaan itu sendiri. Teori ini berpandangan bahwa agen tertentu dalam korporasi dianggap sebagai directing mind atau alter ego. ${ }^{29}$

\section{Doktrin pertanggungjawaban pidana pengganti (vicarious liability)}

Vicarious liability adalah suatu pertanggungjawaban pidana yang dibebankan kepada seseorang atas perbuatan orang lain (the legal responsibility of one person for the wrongful acts another). Dengan demikian dalam pengertian vicarious liability ini, walaupun seseorang tidak melakukan sendiri suatu tindak pidana dan tidak mempunyai kesalahan dalam arti yang biasa, ia masih tepat dapat dipertanggungjawabkan. ${ }^{30}$

Teori ini bertolak dari doktrin "respondeat superior" dan didasarkan pada "employment principle", bahwa majikan (employer) adalah penanggung jawab utama dari perbuatan para buruh/karyawan, jadi the servant's act is the master's act in law. Bertolak dari employment principle dalam hubungannya dengan vicarious liability, Peter Gillies membuat beberapa preposisi sebagai berikut:

a. Suatu perusahaan (seperti halnya dengan manusia sebagai pelaku/pengusaha) dapat bertanggungjawab secara mengganti untuk perbuatan yang dilakukan oleh karyawan/agennya. Pertanggungjawaban demikian hanya timbul untuk delik yang mampu dilakukan secara vicarious.

${ }^{27}$ Muladi \& Priyatno, D. (2012). Pertanggungjawaban Pidana Korporasi. Jakarta. Kencana Prenada Media Group. h. 86.

28 Arief, B. N. (2003). Kapita Selekta Hukum Pidana. Bandung. PT. Citra Aditya Bakti. h. 233.

${ }^{29}$ Setiadi, E. \& Yulia, R.(2010). Hukum Pidana Ekonomi. Yogyakarta. Graha Ilmu. h. 64.

${ }^{30}$ Muladi \& Priyatno, D., op.cit., h. 113-114. 
b. Dalam hubungannya dengan employment principle, delik-delik ini sebagian besar atau seluruhnya merupakan summary offences yang berkaitan dengan peraturan perdagangan.

c. Kedudukan majikan atau agen dalam ruang lingkup pekerjaannya, tidaklah relevan menurut doktrin ini. Tidaklah penting bahwa majikan, baik sebagai korporasi maupun secara alami, tidak telah mengarahkan atau memberi petunjuk/perintah pada karyawan untuk melakukan pelanggaran terhadap hukum pidana. (Bahkan dalam beberapa kasus, vicarious liability dikenakan terhadap majikan walaupun karyawan melakukan perbuatan bertentangan dengan instruksi, berdasarkan alasan bahwa perbuatan karyawan dipandang sebagai telah melakukan perbuatan itu dalam ruang lingkup pekerjaannya.) Oleh karena itu, apabila perusahaan terlibat, pertanggungjawaban muncul sekalipun perbuatan itu dilakukan tanpa menunjuk pada orang senior dalam perusahaan. ${ }^{31}$

Teori ini juga bisa didasarkan "the delegation principle". Jadi, a guilty mind dari buruh/karyawan dapat dihubungkan ke majikan apabila ada pendelegasian kewenangan dan kewajiban yang relevan (harus ada a relevan delegation powers and duties) menurut undang-undang. ${ }^{32}$

3. Doktrin pertanggungjawaban pidana (PJP) yang ketat menurut undang-undang (strict liability)

Pertanggungjawaban pidana korporasi dapat juga semata-mata berdasarkan undangundang, terlepas dari doktrin identification dan doktrin vicarious liability, yaitu dalam hal korporasi melanggar atau tidak memenuhi kewajiban/kondisi/situasi tertentu yang ditentukan oleh undang-undang. Pelanggaran kewajiban/kondisi/situasi tertentu oleh korporasi ini dikenal dengan istilah companies offence, situational offence atau strict liability offences. ${ }^{33}$

Menurut doktrin strict liability (pertanggungjawaban yang ketat), seseorang sudah dapat dipertanggungjawabkan untuk tindak pidana tertentu walaupun pada diri orang itu tidak ada kesalahan (mens rea). Secara singkat, strict liability diartikan sebagai liability without fault. ${ }^{34}$ Pelaku sudah dapat dipidana jika ia telah melakukan perbuatan yang dilarang sebagaimana yang telah dirumuskan dalam undang-undang tanpa melihat lebih jauh sikap batin pelaku.

Doktrin ini tidak mempersoalkan adanya mens rea karena unsur pokok dari strict liability adalah actus reus (perbuatan) sehingga yang harus dibuktikan adalah actus reus (perbuatan) bukan mens rea (kesalahan). Alasan untuk menggunakan konsep strict liability terhadap korporasi yang melakukan tindak pidana tanpa melihat kesalahan di dalamnya lebih didasarkan kepada asas res ipsa loquitur (fakta sudah berbicara) suatu asas yang berpandangan bahwa ada tidaknya pertanggungjawaban pidana tidak

\footnotetext{
31 Arief, B. N., op.cit., h. 236-237.

32 Arief, B. N. op.cit., h. 237.

33 Arief, B. N. op.cit., h. 237-238.

34 Muladi \& Priyatno, D., op.cit., h. 111.
} 
didasarkan pada adanya kesalahan pada diri pelaku (korporasi) tapi didasarkan pada berbahayanya perbuatan itu. ${ }^{35}$

Jadi meskipun undang-undang tidak mencantumkan dengan tegas mengenai dasar pembebanan pertanggungjawaban pidana bagi korporasi, tetapi model dan teori pertanggungjawaban pidana korporasi yang telah ada dan berkembang dapat dijadikan dasar dibebankannya pertanggungjawaban pidana bagi korporasi. Hal ini pula yang mempengaruhi pengaturan korporasi sebagai subjek tindak pidana jual beli organ tubuh manusia yang dapat dibebani pertanggungjawaban pidana.

Hukum memberikan kemungkinan korporasi sebagai subjek hukum pidana, maka memberikan kemungkinan penjatuhan pidana bagi korporasi, berarti pula memberikan kemungkinan korporasi untuk dibebani pertanggungjawaban pidana. Sistem pertanggungjawaban pidana korporasi dalam hukum pidana tidak dapat dilepaskan dengan upaya penanggulangan kejahatan pada hakikatnya merupakan bagian integral dari upaya perlindungan masyarakat (social defence) dan upaya mencapai kesejahteraan masyarakat (social welfare). ${ }^{36}$

Menurut Pasal 201 UU Kesehatan, dalam hal tindak pidana jual beli organ tubuh manusia sebagaimana dimaksud dalam Pasal 192 dilakukan oleh korporasi, maka selain pidana penjara dan denda terhadap pengurusnya, pidana yang dapat dijatuhkan terhadap korporasi yaitu berupa pidana denda dengan pemberatan 3 (tiga) kali dari pidana denda sebagaimana dimaksud dalam Pasal 192. Selain pidana denda sebagaimana dimaksud pada ayat (1), korporasi dapat dijatuhi pidana tambahan berupa pencabutan izin usaha dan/atau pencabutan status badan hukum.

Menurut Pasal 90 UU Perlindungan Anak, dalam hal tindak pidana jual beli organ tubuh anak sebagaimana dimaksud dalam Pasal 85 ayat (1) dilakukan oleh korporasi, maka pidana dapat dijatuhkan kepada pengurus dan/atau korporasinya. Pidana yang dijatuhkan kepada korporasi hanya pidana denda dengan ketentuan pidana denda yang dijatuhkan ditambah $1 / 3$ (sepertiga) pidana denda sebagaimana dimaksud dalam Pasal 85 ayat (1).

Berdasarkan Pasal 201 UU Kesehatan dan Pasal 90 UU Perlindungan Anak, dalam hal tindak pidana jual beli organ tubuh manusia dilakukan oleh korporasi, maka baik pengurus korporasi maupun korporasi itu sendiri dapat dipertanggungjawabkan pidana. Hanya saja terdapat perbedaan ancaman pidana bagi pengurus korporasi dengan korporasi, mengingat korporasi hanya dapat dikenakan pidana denda dan tidak dapat dikenakan pidana penjara, maka yang dapat dikenakan pidana penjara selayaknya orang perseorangan adalah pengurus korporasi.

Akan tetapi, persoalan yang muncul kemudian adalah manakala korporasi tidak dapat membayar pidana denda yang dijatuhkan kepadanya, mengingat UU Kesehatan maupun UU Perlindungan Anak tidak mengatur mengenai pidana pengganti denda untuk korporasi apabila pidana denda tidak dibayar. Mengacu pada ketentuan Pasal 30 ayat (2) KUHP mengatur, "Jika pidana denda tidak dibayar, ia diganti dengan

\footnotetext{
35 Setiadi, E. \& Yulia, R. op.cit., h. 62.

36 Anwar, Y. \& Adang. (2010). Kriminologi. Bandung. PT. Refika Aditama. h. 240.
} 
pidana kurungan". Selanjutnya Pasal 30 ayat (3) KUHP mengatur, "Lamanya pidana kurungan pengganti paling sedikit satu hari dan paling lama enam bulan".

Sebagaimana diketahui bahwa KUHP hanya mengenal orang perseorangan sebagai subjek tindak pidana, dengan perkataan lain KUHP tidak mengenal korporasi sebagai subjek tindak pidana. Oleh sebab itu, pidana kurungan pengganti denda hanya dapat dibebankan kepada subjek hukum "orang perseorangan", tidak untuk korporasi. Disamping itu, pidana kurungan merupakan salah satu bentuk pidana perampasan kemerdekaan, yang hanya dapat dijatuhkan kepada subjek hukum "orang perseorangan" sebagai manusia alamiah (natuurlijk persoon). Dengan demikian, pidana kurungan pengganti tidak dapat dibebankan kepada korporasi. Berbeda halnya apabila pengurus korporasi yang dijatuhkan pidana denda, maka pidana kurungan pengganti denda dapat dibebankan kepada pengurus korporasi seperti halnya orang perseorangan.

Melihat adanya kekosongan norma mengenai pidana pengganti denda untuk korporasi sebagai pelaku tindak pidana jual beli organ tubuh manusia dalam hukum positif di Indonesia, maka perlu untuk melakukan pembaharuan terhadap UU Kesehatan dan UU Perlindungan Anak dengan mengadakan formulasi mengenai pidana pengganti denda untuk korporasi. Pidana pengganti denda untuk korporasi memiliki urgensi agar korporasi tidak terlepas dari jeratan pertanggungjawaban pidana.

Berdasarkan uraian diatas, dapat dipahami bahwa model pertanggungjawaban pidana bagi korporasi sebagai pelaku tindak pidana jual beli organ tubuh manusia dalam hukum positif di Indonesia mengarah kepada lebih dari satu model, yaitu: "pengurus korporasi dan/atau korporasi berkedudukan sebagai pembuat maka pengurus korporasi dan/atau korporasi dapat dibebani pertanggungjawaban pidana". Pengaturan demikian juga sangat dipengaruhi oleh teori-teori pertanggungjawaban pidana bagi korporasi, seperti: identification theory, vicarious liability, dan strict liability.

Jadi jelas bahwa pertanggungjawaban pidana yang dapat dibebankan bagi pelaku tindak pidana jual beli organ tubuh manusia adalah orang perseorangan dan korporasi. Oleh karena itu, tidak hanya orang perseorangan yang melakukan jual beli organ tubuh manusia yang dapat dibebankan pertanggungjawaban pidana, namun manakala pihak Rumah Sakit maupun badan hukum lainnya melakukan jual beli organ tubuh manusia dalam rangka pelaksanaan transplantasi organ tubuh demi mendapatkan keuntungan dapat pula dibebankan pertanggungjawaban pidana.

\subsection{Pertanggungjawaban Pidana Bagi Pelaku Tindak Pidana Jual Beli Organ Tubuh Manusia Dalam Pembaharuan Hukum Pidana Indonesia}

Selama beberapa dekade terakhir, badan legislatif Indonesia berusaha mewujudkan upaya pembaharuan hukum pidana nasional untuk menggantikan KUHP (WvS) sebagai produk hukum warisan pemerintahan zaman kolonial Belanda dan menghasilkan KUHP baru dalam bentuk kodifikasi dan unifikasi sesuai dengan perkembangan kehidupan berbangsa dan bernegara. Dirumuskannya berbagai jenis tindak pidana khusus di luar KUHP ke dalam RUU-KUHP Nasional adalah salah satu upaya pembaharuan hukum pidana nasional yang cukup signifikan dilakukan. 
Dalam RUU-KUHP Nasional (Rancangan Tahun 2015) dirumuskan suatu tindak pidana yang secara implisit meliputi jual beli organ tubuh manusia, yakni terdapat pada Bab VIII tentang Tindak Pidana yang Membahayakan Keamanan Umum bagi Orang, Kesehatan, Barang, dan Lingkungan Hidup, pada Bagian Kesembilan tentang Perbuatan yang Membahayakan Nyawa atau Kesehatan, pada Paragraf 2 tentang Transplantasi Organ Tubuh, pada Pasal 393 yang mengatur:

"Setiap orang yang melakukan perbuatan dengan tujuan komersial dalam pelaksanaan transplantasi organ tubuh atau jaringan tubuh atau transfusi darah dipidana dengan pidana penjara paling lama 5 (lima) tahun dan pidana denda paling banyak Kategori IV." Pidana denda kategori IV berdasarkan Pasal 80 ayat (3) huruf d adalah $\operatorname{Rp} 300.000 .000,00$ (tiga ratus juta rupiah).

Subjek tindak pidananya dirumuskan dengan "setiap orang", dimana berdasarkan Pasal 209 RUU-KUHP Nasional diatur bahwa "setiap orang adalah orang perseorangan termasuk korporasi". Sehingga subjek tindak pidana yang dapat dipertanggungjawabkan pidana adalah orang perseorangan dan korporasi. Yang dimaksud dengan korporasi berdasarkan Pasal 182 RUU-KUHP Nasional adalah kumpulan terorganisasi dari orang dan/atau kekayaan, baik merupakan badan hukum maupun bukan badan hukum.

Berdasarkan Pasal 393 RUU-KUHP Nasional, pidana yang dapat dijatuhkan terhadap subjek tindak pidana "orang perseorangan" adalah pidana penjara paling lama 5 (lima) tahun dan pidana denda paling banyak Kategori IV yaitu Rp 300.000.000,00 (tiga ratus juta rupiah). Pidana ini merupakan pidana yang bersifat kumulatif, yakni gabungan antara dua jenis pidana pokok berupa pidana penjara dan pidana denda.

Berdasarkan Pasal 49 RUU-KUHP Nasional, jika tindak pidana dilakukan oleh korporasi, pertanggungjawaban pidana dikenakan terhadap korporasi dan/atau pengurusnya. Terhadap pengurus korporasi diancam pidana penjara dan denda sebagaimana halnya dengan pidana yang diancamkan terhadap orang perseorangan. Mengingat dalam hal korporasi tidak dapat dijatuhkan pidana penjara, maka korporasi hanya dapat dikenakan pidana pokok berupa denda. Ketentuan Pasal 80 ayat (4) RUUKUHP Nasional mengatur, "Pidana denda paling banyak untuk korporasi adalah kategori lebih tinggi berikutnya", sehingga pidana denda paling banyak untuk korporasi adalah kategori V yaitu Rp 1.200.000.000,00 (satu miliar dua ratus juta rupiah).

Hal yang masih akan menjadi masalah adalah apabila korporasi tidak membayar pidana denda yang telah dijatuhkan kepadanya sesuai putusan hakim, maka korporasi yang bersangkutan akan dikenakan pidana pengganti denda. RUU-KUHP Nasional mengatur secara eksplisit mengenai pidana pengganti denda untuk korporasi terdapat pada Bab III tentang Pemidanaan, Pidana, dan Tindakan, pada Bagian Kedua tentang Pidana, pada Paragraf 2 tentang Pidana Pengganti Denda untuk Korporasi, pada Pasal 85 yang mengatur, "Jika pengambilan kekayaan atau pendapatan sebagaimana dimaksud dalam Pasal 82 ayat (2) tidak dapat dilakukan maka untuk korporasi dikenakan pidana pengganti berupa pencabutan izin usaha atau pembubaran korporasi." Pasal 82 RUU-KUHP Nasional mengatur : 
(1) Pidana denda dapat dibayar dengan cara mencicil dalam jangka waktu sesuai dengan putusan hakim.

(2) Jika pidana denda sebagaimana dimaksud pada ayat (1) tidak dibayar penuh dalam jangka waktu yang ditetapkan maka untuk pidana denda yang tidak dibayar tersebut dapat diambil dari kekayaan atau pendapatan terpidana.

Berdasarkan hal di atas, apabila korporasi tidak membayar penuh pidana denda dalam jangka waktu yang ditetapkan sesuai putusan hakim, maka untuk pidana denda yang tidak dibayar tersebut dapat diambil dari kekayaan atau pendapatan korporasi, dan jika pengambilan kekayaan atau pendapatan tidak dapat dilakukan maka untuk korporasi dikenakan pidana pengganti berupa pencabutan izin usaha atau pembubaran korporasi.

\section{Kesimpulan}

Pertanggungjawaban pidana yang dapat dibebankan bagi pelaku tindak pidana jual beli organ tubuh manusia menurut peraturan perundang-undangan Indonesia adalah orang perseorangan dan korporasi. Oleh karena itu, tidak hanya orang perseorangan yang melakukan jual beli organ tubuh manusia yang dapat dibebankan pertanggungjawaban pidana, namun manakala pihak rumah sakit maupun badan hukum lainnya melakukan jual beli organ tubuh manusia dalam rangka pelaksanaan transplantasi organ tubuh demi mendapatkan keuntungan dapat pula dibebankan pertanggungjawaban pidana. RUU-KUHP Nasional sebagai bentuk adanya pembaharuan hukum pidana di Indonesia menegaskan pula bahwa orang perseorangan dan korporasi dapat dibebankan pertanggungjawaban pidana terkait tindak pidana jual beli organ tubuh manusia. RUU-KUHP Nasional juga melengkapi kelemahan hukum positif dengan mengatur sanksi pidana pengganti denda bagi korporasi.

\section{Daftar Pustaka}

\section{Buku}

Adang, Y. A. (2010). Kriminologi. Bandung: PT Refika Aditama.

Arief, B. N.(2003). Kapita Selekta Hukum Pidana. Bandung; PT. Citra Aditya Bakti.

Chazawi, A. (2007). Malpraktik Kedokteran (Tinjauan Norma dan Doktrin Hukum). Malang; Bayumedia Publishing.

Gunadi, I., \& Efendi, J. (2011). Cepat dan Mudah Memahami Hukum Pidana. Jakarta: Prestasi Pustaka.

Ibrahim, J. (2006). Teori dan Metodeologi Penelitian Hukum Normatif. Malang: Bayu Publishing.

Muladi \& Priyatno, D. (2012). Pertanggungjawaban Pidana Korporasi. Jakarta: Kencana Prenada Media Group.

Setiadi, E. \& Yulia, R.(2010). Hukum Pidana Ekonomi. Yogyakarta: Graha Ilmu. 
Soekanto, S. (2010). Pengantar Penelitian Hukum. Jakarta: UII Press.

Widnyana, I. M. (2010). Asas-Asas Hukum Pidana. Jakarta: Fikahati Anesta.

\section{Peraturan Perundang-Undangan}

Rancangan Undang-Undang tentang Kitab Undang-Undang Hukum Pidana (RUUKUHP Tahun 2012).

Undang-Undang Republik Indonesia Nomor 36 Tahun 2009 tentang Kesehatan, Lembaran Negara Republik Indonesia Tahun 2009 Nomor 144, Tambahan Lembaran Negara Republik Indonesia Nomor 5063.

Undang-Undang Republik Indonesia Nomor 23 Tahun 2002 tentang Perlindungan Anak, Lembaran Negara Republik Indonesia Tahun 2002 Nomor 109, Tambahan Lembaran Negara Republik Indonesia Nomor 4235.

\section{Jurnal}

Aristantie, D. W. (2014). Perjanjian Antara Pendonor Dan Pasien Yang Membutuhkan "Ginjal" Untuk Transplantasi (Analisis Pasal 64 Undang-Undang Republik Indonesia No 36 Tahun 2009 Tentang Kesehatan). Kumpulan Jurnal Mahasiswa Fakultas Hukum,1(1).

Bintoro, A. (2018). Memahami Nilai Etika Dan Moral Donasi Organ. Jurnal Orientasi Baru, 25(1). 93-110

Herani, I. (2017). Organ Donation? Why Not..: Keputusan Untuk Mendonorkan Organ Tubuh (studi pada living donor). PSIKOVIDYA, 21(2).

Hidayati, M. N. (2012). Upaya Pemberantasan dan Pencegahan Perdagangan Orang Melalui Hukum Internasional dan Hukum Positif Indonesia. Jurnal Al-Azhar Indonesia Seri Pranata Sosial, 1(3), 163-175.

Iqbal, M. (2017, December). Perkembangan Kejahatan Dalam Upaya Penegakan Hukum Pidana: Penanggulangan Kejahatan Profesional Perdagangan Organ Tubuh Manusia. In PROCEEDINGS (Vol. 2, No. 1), 307-324.

Laki, Y. A. (2015). Tindak Pidana Perdagangan Organ Tubuh Manusia Menurut Ketentuan Hukum Positif Indonesia. Lex et Societatis, 3(9), 117-123.

Lintang, R. (2013). Aspek Hukum Terhadap Pemanfaatan Organ Tubuh Manusia Untuk Kelangsungan Hidup. LEX ET SOCIETATIS, 1(5). 132-143.

Paminto, S. R. (2017). Dehumanisasi Penjualan Organ Tubuh Manusia Berdasarkan Hukum Positif. Jurnal Wawasan Yuridika, 1(2), 174-190.

Pasaribu, M., Hamdan, M., \& Lubis, R. (2014). Perdagangan Organ Tubuh Manusia Untuk Tujuan Transplantasi Dari Perspektif Kebijakan Hukum Pidana Di Indonesia. Jurnal Mahupiki, 2(1).

Putra, F. A. (2013). Analisis Yuridis Perundang-undangan Terkait Tindak Pidana Jual Beli Organ Tubuh untuk Kepentingan Transplantasi Organ Ginjal (Studi 
Perbandingan antara Indonesia dengan Philipina). Kumpulan Jurnal Mahasiswa Fakultas Hukum, 1(2).

Simanjuntak, N. A. L. (2017). Kajian Yuridis Ketentuan Pidana Dalam Pasal 192 Undang-Undang Nomor 36 Tahun 2009 Tentang Kesehatan Terkait Dengan Jual Beli Organ Tubuh Manusia Untuk Tindakan Transplantasi. Kumpulan Jurnal Mahasiswa Fakultas Hukum.

Suminar, S. R. (2017). Aspek Hukum dan Fiqih Tentang Transaksi Organ Tubuh untuk Transplantasi Organ Tubuh Manusia. Syiar Hukum, 12(1), 33-48.

\section{Tesis atau Desertasi}

Khalifah, H., \& Innaka, R. A. (2016). Tinjauan Yuridis Terhadap Praktik Jual-Beli Ginjal Berdasarkan Peraturan Perundang-Undangan di Indonesia (Doctoral dissertation, Universitas Gadjah Mada).

Woriassy, E. Y. (2012). Efektifitas Ketentuan Hukum Tentang Tindak Pidana Jual Beli Organ Dan Atau Jaringan Tubuh (Doctoral dissertation, UAJY).

\section{Berita dalam Situs Internet :}

Anonim, Video: Terdesak Himpitan Ekonomi, Ibu Ini Berniat Jual Ginjal, tersedia pada url: m.liputan6.com/tv/read/2621557/video-terdesak-himpitan-ekonomi-ibuini-berniat-jual-ginjal, diakses pada tanggal 10 Oktober 2016 pukul 22.38 WITA. 